\title{
Prevalence of myopia and associated risk factors in medical students in Monterrey
}

\section{Prevalencia de miopía y factores de riesgo asociados en estudiantes de medicina en Monterrey}

\author{
Christian G. Cavazos-Salias ${ }^{1 \#, ~ N a t a l i a ~ M o n t e m a y o r-S a l d a n ̃ a ~}{ }^{1 \#, ~ L u c y ~ S a l u m-R o d r i ́ g u e z " 1, ~}$ \\ Juan E. Villarreal-Del Moral ${ }^{1}$ and Manuel Garza-Leon ${ }^{1,2 *}$ \\ ${ }^{1}$ Department of Clinical Sciences, Health Sciences Division, Universidad de Monterrey, San Pedro Garza García, Nuevo León; ${ }^{2}$ Hospital Dr. Luís \\ Sánchez Bulnes, Asociación para Evitar la Ceguera en Mexico, Mexico City, Mexico \\ "Both authors contributed similarly, so they have the same recognition
}

\begin{abstract}
Background and objective: Myopia has become a public health problem, so it is important to know the prevalence of myopia in different populations, like in medical students who are considered a risk group. Our objective was to know the prevalence of myopia in medical students of the University of Monterrey, as well as to study the associated risk factors. Methods: A prospective, cross-sectional, and observational study was conducted between October and December 2016. Three hundred medical students were evaluated regarding the presence of refractive errors through auto-kerato/refractometer measurement and a questionnaire to analyze the presence of known risk factors for myopia. Results: One hundred eighty-nine students (68.7\%) had myopia in one eye, and 149 (54.2\%) in both. From the factors evaluated, only two were statistically significant. One was that patients with myopia were older than those without it $(21.60 \pm 2.27$ vs. $20.77 \pm 2.61$, respectively; $p=0.01)$, and the second one was a history of the need of visual correction in all siblings (29.1 vs. $17.4 \%$ respectively; $p=0.04)$. Reading time, computer use, exercise time, overweight/obesity, having parents or one sibling who needs visual correction were similar between groups. Conclusions: In this group of medical students, the prevalence of myopia based on refraction without cycloplegia is higher compared to other demographic groups of the Americas, and the only associated risk factors were age and need of visual correction in all siblings.
\end{abstract}

Key words: Myopia. Prevalence. Risk factors. Medical students.

\section{Resumen}

Antecedentes y objetivo: La miopía se ha convertido en un problema de salud pública, por lo que es importante conocer su prevalencia en diferentes grupos poblacionales, los estudiantes de medicina son considerados un grupo de riesgo. Nuestro objetivo fue conocer la prevalencia de miopía en los estudiantes de medicina de la Universidad de Monterrey, así como estudiar los factores de riesgo asociados. Métodos: Estudio prospectivo, transversal y observacional, realizado entre octubre y diciembre de 2016. Se evaluaron 300 estudiantes de medicina. La presencia de error refractivo se evaluó mediante

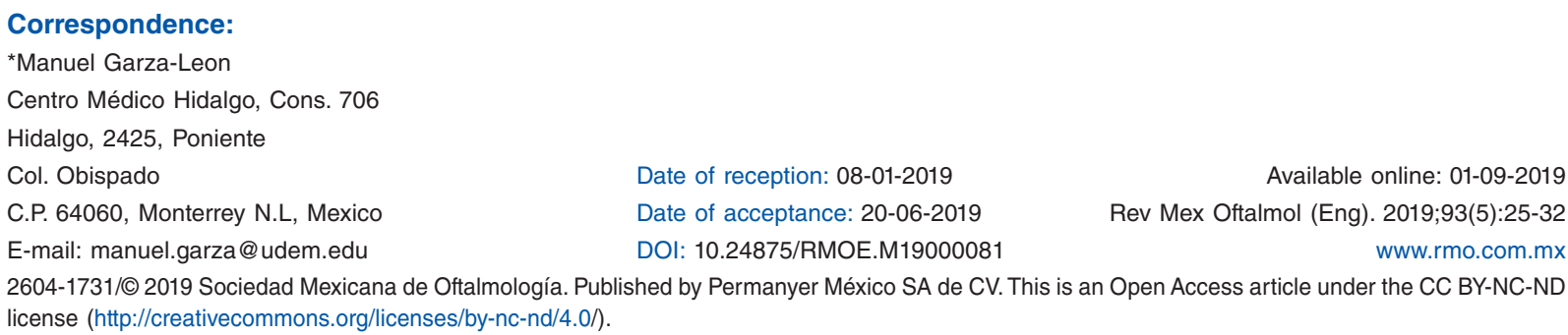

Date of reception: 08-01-2019 Date of acceptance: 20-06-2019 DOI: 10.24875/RMOE.M19000081

Available online: 01-09-2019 Rev Mex Oftalmol (Eng). 2019;93(5):25-32

www.rmo.com.mx 2604-1731/@ 2019 Sociedad Mexicana de Oftalmología. Published by Permanyer México SA de CV. This is an Open Access article under the CC BY-NC-ND license (http://creativecommons.org/licenses/by-nc-nd/4.0/). 
un autoquerato refractómetro, y la presencia de factores de riesgo conocidos de miopía se analizó mediante un cuestionario. Resultados: 189 alumnos (68.7\%) tuvieron miopía en algún ojo y 149 (54.2\%), en ambos ojos. De los factores estudiados, solo en dos hubo una diferencia estadísticamente significativa: los pacientes con miopía tuvieron mayor edad que los que no la presentaron ( $21.60 \pm 2.27$ vs. $20.77 \pm 2.61$, respectivamente), con una $p=0.01$, además del antecedente de todos los hermanos usuarios de lentes (29.1 vs. $17.4 \%$, respectivamente), con una $p=0.04$. Las horas de lectura, el uso de computadora, el tiempo de ejercicio, el sobrepeso/obesidad, el tener padres o algún hermano que utilizan lentes fueron similares en ambos grupos. Conclusiones: En este grupo de alumnos de medicina, la prevalencia de miopía basada en una refracción sin ciploplegia es más alta que en otros grupos étnicos del continente americano, y los únicos factores de riesgo asociados fueron la edad y el que todos los hermanos utilicen lentes.

Palabras clave: Miopía. Prevalencia. Factores de riesgo. Estudiantes de medicina.

\section{Introduction}

Myopia is one of the most frequent ophthalmic disorders and is defined as a spherical refractive error caused by an excessive refractive power in relation to the corneal curvature and lens thickness and/or increased anteroposterior diameter of the eyeball, which produce refraction of the light to a focal point in front of the retina.

Studies in different parts of the world ${ }^{1-3}$ have shown in recent decades a large increase in the prevalence of myopia, especially in Asian countries ${ }^{2,4}$, which is why several studies have been conducted to find the factors responsible for this changes ${ }^{2,5-7}$.

The etiology of myopia is multifactorial; several studies have evaluated multiple factors associated with the development or progression of myopia in different populations. A review by Foster et al., in $2014^{8}$, concluded that myopia is the result of a complex interaction between genetic predisposition ${ }^{9,10}$ and other environmental factors, such as physical activity ${ }^{11}$, outdoor activities $^{12,13}$, sleep hours ${ }^{14}$, weight and height ${ }^{15}$, and among others. Mirshahi et al. ${ }^{16}$ observed that people with university degrees had a higher prevalence of myopia compared to people with lower levels of education, while Fernández-Montero et al. ${ }^{17}$ conducted a study in an open selection cohort and concluded that exposure to and use of computers is associated with the development and progression of myopia. These factors have been confirmed in other epidemiological studies ${ }^{8,18}$.

Studies in students from various areas have shown a high prevalence of myopia ${ }^{4,19,20}$, possibly related to spending a good part of the day in near vision activities $^{19,20}$, as well as the frequent use of the computer and reading hours ${ }^{17}$. Among the groups with the highest prevalence are medical students $\mathrm{s}^{4,18,20-26}$. This may be a consequence of spending a large number of hours reading, performing near vision activities and using electronic devices ${ }^{17}$. Because of this, medical students are considered a population with a high predisposition to myopia ${ }^{21}$.

To the best of our knowledge, there is no information in Mexico about the prevalence of refractive errors in a student population; in addition, it has not been confirmed that the risk factors described in other populations are similar to those on our population, so the objective of our work was to estimate the prevalence of myopia in medical students of the University of Monterrey, as well as to study the risk factors for the development of the disease.

\section{Materials and methods}

A prospective, cross-sectional, and observational study was conducted between October and December 2016, in which refractive errors were evaluated, as well as the associated risk factors through a questionnaire, which included relatives with refractive errors (defined as the use of eyeglasses for far vision and/or history of refractive surgery), order of birth in the family, eye diseases, hours of physical activity, hours of reading per week, and hours of computer use per week, with a total of 24 questions. Furthermore, height and weight were measured (with a Beurer BG-17 Scale), and body mass index (BMI) was calculated.

Refractive error measurement was performed automatically with the use of an auto kerato-refractometer (Topcon RM-A7000, Topcon Co., Tokyo, Japan) without the use of cycloplegic drops. Refractive error was considered as the average of three measurements.

Myopia was defined as a spherical equivalent (SE)of -0.50 diopters (D). High myopia was defined as a refractive error equal to or greater than $-6.0 \mathrm{D}$. Overweight/obesity was defined as a BMI greater than $24.9 \mathrm{~kg} / \mathrm{m}^{2}$.

Before study initiation, the approval of the authorities and the Ethics Committee of the University of Monterrey was obtained, and the study adhered to the 
principles of the Declaration of Helsinki. Informed consent was obtained from all participants after explaining the study.

\section{Sample size}

The target population was the medical students of the University of Monterrey. The sample size was estimated using a formula for comparing independent proportions, according to the average proportion (57\%) described in three studies in different countries ${ }^{27-31}$, with a $5 \%$ error rate and a $95 \%$ confidence interval $(95 \% \mathrm{Cl})$, giving a total of 274 subjects.

\section{Sampling}

Stratified sampling was carried out according to the semester students were enrolled, with a random and proportional selection divided by the expected proportion.

\section{Inclusion and exclusion criteria}

All students enrolled in the fall semester of 2016 at the University of Monterrey who agreed to participate in the study and signed informed consent were included in the study. All students who had a history of any surgical procedure that could modify the refractive state of the eye (refractive surgery, cataract surgery, and retinal surgery), who suffered an active eye infection or who did not cooperate for the study, were excluded from the study.

\section{Statistical analysis}

Data were analyzed using a statistical program (SPSS v21.0; IBM, Chicago, Illinois, USA). The SE of the refractive error was calculated as the sum of the spherical defect plus the sum of half of the cylindrical refractive error calculated in negative. The prevalence was calculated as the number of participants with the particular type of refractive error in relation to the total number of examinees, and the mean \pm standard deviation was reported, as well as the $95 \% \mathrm{Cl}$. The normal distribution of parameters was tested by the Kolmogorov-Smirnov test. In the case of parameters not normally distributed, the Mann-Whitney U-test was used to examine the statistical significance of the difference between the groups. The Chi-square test was used to compare proportions. A linear regression analysis was applied to examine associations between the refractive error and the risk factors studied. Logistic regression was used to compare the prevalence of myopia, and all the factors studied together. The relative risk and its $95 \% \mathrm{Cl}$ were calculated. The results were considered statistically significant when $p<0.05$.

\section{Results}

Two-hundred and seventy-five students with an average age of $21.34 \pm 2.41$ (range 18-37 years) were evaluated. Around $50 \%(56.4 \%)$ of the students (155) were male. Table 1 shows demographic data and risk factors for the population studied. Students with myopia were older than students without it, with statistical significance $(p=0.01)$.

From the total sample, the SE of the right eye was $-0.96 \pm 1.27 D$ (range $-6.00-+2.00$ ) and of the left eye was $-0.94 \pm 1.35 D$ (range $-6.00-+2.50$ ). Myopia (SE $\leq-0.50 \mathrm{D})$ was observed in 189 students, in any eye (68.7\%; 95\% Cl: 63.2-74.2\%), and 149 (54.2\%) had myopia in both eyes. Around $60 \%(61.5 \%)$ had myopia in the right eye (SE $\leq-0.50 \mathrm{D})$ and $58.9 \%$ in the left eye. High myopia ( $S E \leq-6.00 \mathrm{D}$ ) was found in six students $(2.18 \%)$, one bilaterally and five only in the left eye $(0.4 \%$ of the right eyes and $2.2 \%$ of the left eyes). The observed refractive errors are shown in figure 1.

From the risk factors studied (prevalence of myopia by gender, being firstborn, having one of the parents or at least one sibling who used eyeglasses, suffering from eye diseases or having obesity), none showed a statistically significant difference, as demonstrated in table 1. However, students in whom all their siblings wore eyeglasses had a higher prevalence of myopia $(p=0.04)$. This was not the case if both parents used eyeglasses (Table 1).

The average weight of the participants was $71.82 \pm$ $18.01 \mathrm{~kg}$ (range 42-138 kg); the average height, 169.49 $\pm 9.13 \mathrm{~cm}$ (range 149-195 cm), and the average BMl, $24.77 \mathrm{mg} / \mathrm{kg}^{2} \pm 4.69$ (range 16.24-46.65 mg/ $/ \mathrm{kg}^{2}$ ). The overweight/obesity rate in students was $40.4 \%$ (111 students), of which $81(73 \%)$ had myopia. Of the students without obesity, $65.9 \%$ (108 students) had myopia $(p=0.212)$.

Sex, being the firstborn, use of eyeglasses by a sibling, all siblings, one of the parents or both parents, eye diseases, reading hours, computer use, obesity and hours of exercise, were studied as possible risk factors in an age-adjusted multivariate logistic regression model (Table 2). 
Table 1. Demographic data and risk factors for the population studied

\begin{tabular}{|l|c|c|c|c|}
\hline Variable & Total $n=275$ & Students with myopia $n=189$ & Students without myopia $n=86$ & p-value \\
\hline Age (years) & $21.34 \pm 2.41$ & $21.60 \pm 2.27$ & $20.77 \pm 2.61$ & 0.01 \\
\hline Sex m/f, $\mathrm{n}(\%)$ & $155 / 120(56.4 / 43.6)$ & $106 / 83(56.1 / 43.9)$ & $49 / 37(57 / 43)$ & 0.89 \\
\hline Firstborn, $\mathrm{n}(\%)$ & $136(49.5)$ & $94(49.7)$ & $42(48.8)$ & 0.89 \\
\hline Siblings with eyeglasses, $\mathrm{n}(\%)$ & $148(53.8)$ & $106(56.1)$ & $42(48.8)$ & 0.26 \\
\hline All siblings with eyeglasses, $\mathrm{n}(\%)$ & $70(25.5)$ & $55(29.1)$ & $15(17.4)$ & 0.04 \\
\hline Any parent with eyeglasses, $\mathrm{n}(\%)$ & $204(74.2)$ & $140(74.1)$ & $64(74.4)$ & 0.95 \\
\hline Both parents with eyeglasses, $\mathrm{n}(\%)$ & $137(49.8)$ & $95(50.3)$ & $42(48.8)$ & 0.82 \\
\hline Ocular diseases, $\mathrm{n}(\%)$ & $11(4)$ & $7(3.7)$ & $4(4.7)$ & 0.71 \\
\hline Reading hours* & $18.22 \pm 15.95$ & $18.63 \pm 16.90$ & $17.34 \pm 13.71$ & 0.53 \\
\hline Hours of computer use* & $36.29 \pm 26.83$ & $37.14 \pm 28.821$ & $34.42 \pm 23.59$ & 0.43 \\
\hline Obesity, \% & 40.4 & 42.9 & 34.9 & 0.21 \\
\hline Hours of exercise* & $3.77 \pm 3.62$ & $3.64 \pm 3.41$ & $4.05 \pm 4.06$ & 0.28
\end{tabular}

*Weekly, f: female; m: male.

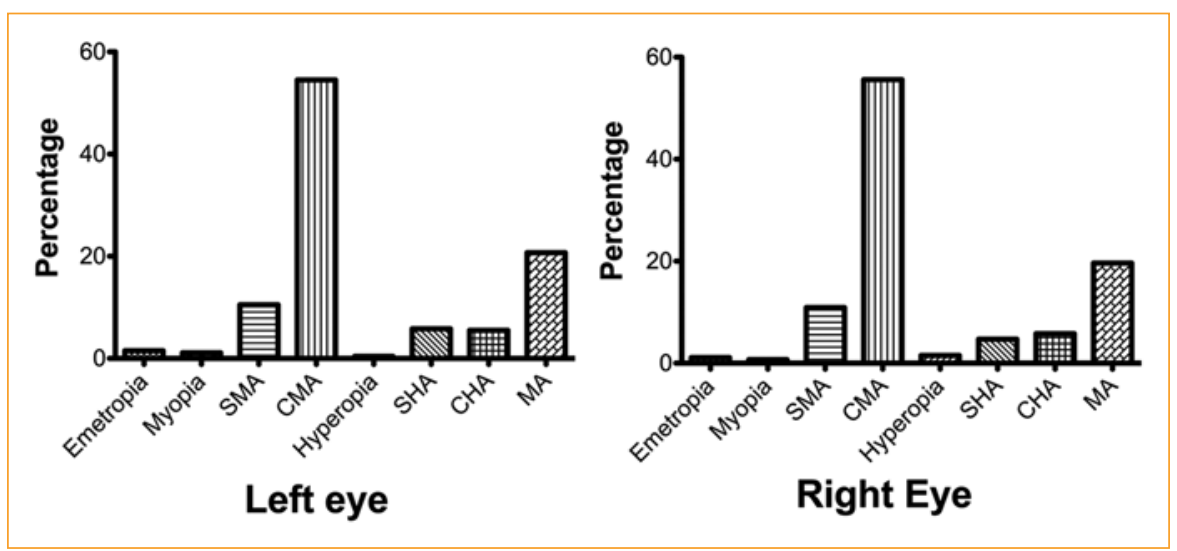

Figure 1. Distribution of refractive errors in medical students.

CHA: compound hyperopic astigmatism; SHA: simple hyperopic astigmatism; MA: mixed astigmatism;

CMA: compound myopic astigmatism; SMA: simple myopic astigmatism.

\section{Discussion}

In this study, we found that the prevalence of myopia in medical students in Monterrey was of $68.7 \%$ (95\% Cl: $63.2-74.2 \%)$. This is higher than the figures reported in studies conducted in European countries, such as that of Midelfart et al. ${ }^{23}$, who, in 1989, found a prevalence of $50.3 \%$ in 133 medical students in Norway, a similar result to that in students in Denmark from 1996 to 1998 that reported $50 \%$. A study in medical students in Turkey between 2003 and 2004 found an even lower prevalence $(32.9 \%)^{18}$. Studies in other regions of the world have reported a higher prevalence, in general, especially in the Asian continent, where the reported prevalence varies between $35.86 \%$ in India in $2014^{27}$, $53.7 \%$ in Saudi Arabia ${ }^{28}, 57.6 \%$ in Pakistan ${ }^{7}$, and $84.1 \%$ in China between 2007 and 2012 20,29 , with the highest reported prevalence in Singapore in 2000, with $89.8 \%$ (95\% Cl: $85.94 \%$ ) and in Taiwan, with $95.8 \%$ between 1987 and 19994. So far, information in the Americas and the Caribbean is very scarce, in Dominica, a study by Halari et al. found a prevalence of $31.9 \%$ in 116 medical 
Table 2. Risk factors associated with myopia (multivariate logistic regression)

\begin{tabular}{|l|l|l|l|}
\hline Variable & $\begin{array}{c}\text { Relative } \\
\text { risk }\end{array}$ & $95 \%$ CI & p-value \\
\hline Gender & 1.03 & $0.62-1.73$ & 0.89 \\
\hline Firstborn & 1.05 & $0.60-1.81$ & 0.85 \\
\hline Any sibling with eyeglasses & 1.04 & $0.55-1.97$ & 0.88 \\
\hline All siblings with eyeglasses & 1.91 & $0.89-4.08$ & 0.09 \\
\hline Any parent with eyeglasses & 0.85 & $0.41-1.78$ & 0.67 \\
\hline $\begin{array}{l}\text { Both parents with } \\
\text { eyeglasses }\end{array}$ & 1.17 & $0.62-2.22$ & 0.62 \\
\hline Ocular diseases & 1.01 & $0.60-1.70$ & 0.95 \\
\hline Reading hours* & 1.02 & $0.56-1.77$ & 0.99 \\
\hline Hours of computer use* & 1.09 & $0.62-1.92$ & 0.73 \\
\hline Obesity, \% & 1.38 & $0.80-2.36$ & 0.24 \\
\hline Hours of exercise* & 1.49 & $0.87-2.54$ & 0.13 \\
\hline
\end{tabular}

*Students with more hours than the mean. Cl: confidence interval.

students ${ }^{30}$, and in Ecuador, of $26.67 \%$ in 180 students in $2013^{31}$. However, the methodology, non-participation rates, and refraction techniques differ, which limits comparisons.

The age of students with myopia was statistically significantly higher than that of students without myopia (-0.83 years; $95 \% \mathrm{Cl}:-0.22--1.44)$. This is consistent with other studies that have shown that at an older age the prevalence of myopia increases due to the late development of myopia as well as its progression ${ }^{7,23,32}$, which has been described especially in medical students, as reported by Midelfart et al. in a group of medical students in Norway, where $43.3 \%$ of students began using eyeglasses at age 19 or later, and generally do not develop high myopia, which is consistent with the results in our students ${ }^{23}$.

The effect of sex hormones on the development and prevalence of myopia has been extensively studied ${ }^{33,34}$. Epidemiological studies have corroborated the higher prevalence of myopia in women, especially high myopia $^{35}$, while other studies have also suggested an environmental effect since the highest prevalence is observed in white women from the East Asian continent after 9 years old ${ }^{36}$. This difference has shown contradictory results in medical students, since some studies, especially in Asian countries, report different rates $7,20,27,29,30$, while others, like ours $(69.2 \%$ in women vs. $68.4 \%$ in men), do not find significant differences ${ }^{18,22,23}$. One of the possible reasons for this is that in our study the prevalence of high myopia was very low; only $2.18 \%$ of the students presented it, and it is in this group of patients that the prevalence is much higher in women than in men $^{35}$.

The order of birth has been reported in some studies as a risk factor for developing myopia ${ }^{5,37-39}$; however, the reported association is low $(\mathrm{OR}<1.3)^{5}$, very similar to that of our study $(1.33 ; 95 \% \mathrm{Cl}: 0.80-2.23)$, although in our study this difference was not statistically significant. This could be due to what was reported by Guggenheim et al., who analyzed the data from four different epidemiological studies and found that only studies with more than 4000 participants provide an adequate statistical power to support this association ${ }^{5}$, a much larger number than in our study. In addition, Morgan et al. suggest that this association could be due to a confounding factor due to the level of education $^{40}$ since some studies report more education in firstborn children than in their siblings ${ }^{6}$, a factor that is obviously absent in our study, since all the subjects evaluated are university students.

The influence of genetics in the development of myopia has been extensively studied ${ }^{8-10,18,41-44}$. Mutations of the LRPAP1, CTSH, LEPREL143, 44, ZNF644, SLC39A5, and SCO2 genes have been studied in

China $^{44}$, as well as their correlation with high myopia. In our study, the genetic influence measured through the prevalence of myopia in parents and siblings did not demonstrate a statistically significant correlation. In the case of parents, a study conducted in China on university students and their parents showed a statistically significant result when parents had myopia ${ }^{45}$; however, this was not the case in our study. Nevertheless, this study does not rule out the influence of environmental factors that could affect the development of the disease.

In our study, we found that the prevalence of myopia was higher when all siblings used eyeglasses; this result is similar to that found by Czepita et al., in Poland ${ }^{42}$, who studied 5533 students with a methodology very similar to ours and obtained statistically significant results for the correlation between the frequency of myopia in students and the fact that their parents or siblings were myopic $(p<0.001)$.

The relationship between exercise and the development of myopia has been studied in several countries, with conflicting results ${ }^{11,12,46,47}$. In Australia ${ }^{46}$, a study of a group of university students between 18 and 25 years of age did not find an important correlation between exercise and the amount of exercise with the presence 
and severity of myopia. We obtained similar results; however, the sample of the Australian study was small (27 subjects), and this is a factor that can alter the results. On the other hand, a 2-year longitudinal cohort study that evaluated physical activity as a protective factor for the development of the disease in Denmark ${ }^{11}$, with a focus on medical students, concluded that there is a correlation with exercise as a protective factor. Other studies ${ }^{47}$ have had similar results to ours.

In our study, we observed that computer use above the mean value $(36.29 \pm 26.82 \mathrm{~h} /$ week $)$ did not correlate with the presence of myopia. This contrasts with a cohort study conducted by Fernández-Montero et al., in $2015^{17}$, where 17,217 university students from Spain were evaluated, with an average computer use of $14.3 \mathrm{~h} /$ week and found a correlation between computer use and the development and or progression of myopia. This is despite the fact that in our study, the students spent a greater number of hours using the computer than in the mentioned study; however, their sample size is much larger than ours.

Some reports in literature have documented the correlation between the level of education and near vision activities, mainly reading, so there is multiple evidence supporting that the level of education ${ }^{3,16}$, a high socioeconomic level ${ }^{48}$, and more near-vision activities ${ }^{49}$, and as risk factors for myopia; however, the exact mechanisms on how the development of this disease are favored to remain controversial. In a study conducted in a pediatric Australian population, Ip et al. found that longer reading time at a short distance $(<30 \mathrm{~cm})$ was associated with a higher prevalence of myopia, even after adjusting for age, sex, ethnicity, and schooling $(p=0.02 \text { and } p=0.0003 \text {, respectively })^{50}$. Regarding the hours of reading, in our participants, $33.1 \%$ (91) were above the mean of $18.22 \pm 15.95 \mathrm{~h} /$ week, and similarly, $38.9 \%$ (107) spent more than $40 \mathrm{~h}$ in front of an electronic device.

It has been studied whether anthropometric characteristics (weight, height, and BMI) favor the development of myopia ${ }^{15,51-53}$. In our study, there was no correlation between them and the presence of myopia, similar to that reported by other authors ${ }^{51,52}$. One of the studies with the largest sample size, conducted by Rosner et al..$^{51}$ in more than 100,000 men between the ages of 17 and 19, found that myopia was not associated with a higher height or weight since people with high myopia had a lower BMI compared to those who suffered from moderate myopia or were emmetropic. In accordance, Saw et al. ${ }^{52}$ studied the correlation between anthropometric measurements of children in
China and ocular parameters and their refraction and found that children with higher BMI tended to be hyperopic. In our study, there was no correlation between overweight/obesity and myopia.

Our study has some limitations, the most important being the measurement of the refractive error by auto refractometer without using cycloplegic drops; however, this is a common practice in population studies in adults $^{35}$, and there is controversy about the effect of accommodation on non-cycloplegic measurement of refraction in adults, since some studies report that in adults there is a measurement error ${ }^{54-56}$ generally lower than $0.50 D^{56}$; while other studies, such as the one published by Sanfilippo et al. ${ }^{57}$, suggest that in adults 20 years of age and older, it is not necessary to perform cycloplegic refraction. Our largest group of students belongs to that age range. On the other hand, to evaluate the effect of the use of eyeglasses by parents and siblings, only one questionnaire was used. This may have caused loss of a percentage of patients that may have a refractive error but do not use eyeglasses. This can be important as reported by Bai et al. in a study in China in 2014 that estimated that from patients who need eyeglasses, $34 \%$ of them do not use their prescription ${ }^{58}$. Finally, the study only evaluated medical students, and although other studies have shown similar rates between medical students $^{35,45}$ and students from other careers ${ }^{19,59}$, it is not possible to generalize our results to every university student.

\section{Conclusions}

In this group of medical students at the University of Monterrey, the prevalence of myopia based on non-cycloplegic refraction is higher than in other ethnic groups of the American continent, and the only associated risk factors were age and use of eyeglasses by all siblings.

\section{Acknowledgments}

Our thanks to the students Montserrat de la Garza, César Gustavo Mendoza Lara, José Iván López Haces, and José Julio Villarreal Tule for their help in measuring students' refractive error.

\section{Conflicts of interest}

The authors declare that they have no conflicts of interest. 


\section{Ethical disclosures}

Protection of human and animal subjects. The authors declare that the procedures followed were in accordance with the regulations of the relevant clinical research ethics committee and with those of the Code of Ethics of the World Medical Association (Declaration of Helsinki).

Confidentiality of data. The authors declare that they have followed the protocols of their work center on the publication of patient data.

Right to privacy and informed consent. The authors have obtained the written informed consent of the patients or subjects mentioned in the article. The corresponding author is in possession of this document.

\section{References}

1. Guo L, Yang J, Mai J, Du X, Guo Y, Li P, et al. Prevalence and associated factors of myopia among primary and middle school-aged students: a school-based study in Guangzhou. Eye (Lond.). 2016;30(6):796-804.

2. Lee YY, Lo CT, Sheu SJ, Yin LT. Risk factors for and progression of myopia in young Taiwanese men. Ophthalmic Epidemiol. 2015;22(1):66-73.

3. Williams KM, Bertelsen G, Cumberland P, Wolfram C, Verhoeven VJ, Anastasopoulos E, et al. Increasing Prevalence of Myopia in Europe and the Impact of Education. Ophthalmology. 2015;122(7):1489-97.

4. Lin LL, Shih YF, Lee YC, Hung PT, Hou PK. Changes in ocular refraction and its components among medical students--a 5-year longitudinal study. Optom Vis Sci. 1996:73(7):495-8.

5. Guggenheim JA, McMahon G, Northstone K, Mandel Y, Kaiserman I, Stone RA, et al. Birth order and myopia. Ophthalmic Epidemiol. 2013; 20(6):375-84.

6. Booth AL, Kee HJ. Birth Order Matters: The Effect of Family Size and Birth Order on Educational Attainment. J Popul Econ. 2009;22(2):367-97.

7. Chaudhry R, Ali $\mathrm{H}$, Sheikh NH. Frequency and underlying factors of myopia among medical students. Biomedica. 2011;27(2):154-60.

8. Foster PJ, Jiang Y. Epidemiology of myopia. Eye (Lond). 2014;28(2):202-8.

9. Kurtz D, Hyman L, Gwiazda JE, Manny R, Dong LM, Wang Y, et al. Role of parental myopia in the progression of myopia and its interaction with treatment in COMET children. Invest Ophthalmol Vis Sci. 2007;48(2):562-70.

10. Lim LT, Gong Y, Ah-Kee EY, Xiao G, Zhang X, Yu S. Impact of parental history of myopia on the development of myopia in mainland china school-aged children. Ophthalmol Eye Dis. 2014:6:31-5.

11. Jacobsen $N$, Jensen $H$, Goldschmidt $E$. Does the level of physical activity in university students influence development and progression of myopia?--a 2-year prospective cohort study. Invest Ophthalmol Vis Sci. 2008;49(4):1322-7.

12. Jin JX, Hua WJ, Jiang X, Wu XY, Yang JW, Gao GP, et al. Effect of outdoor activity on myopia onset and progression in school-aged children in northeast China: the Sujiatun Eye Care Study. BMC Ophthalmol. 2015;15:73.

13. McKnight CM, Sherwin JC, Yazar S, Forward H, Tan AX, Hewitt AW, et al. Myopia in young adults is inversely related to an objective marker of ocular sun exposure: the Western Australian Raine cohort study. Am J Ophthal. 2014;158(5):1079-85

14. Jee D, Morgan IG, Kim EC. Inverse relationship between sleep duration and myopia. Acta Ophthalmol. 2015:94(3):e204-10.

15. Rim TH, Kim SH, Lim KH, Kim HY, Baek SH. Body Stature as an Age-Dependent Risk Factor for Myopia in a South Korean Population. Semin Ophthalmol. 2017;32(3):326-36.

16. Mirshahi A, Ponto KA, Hoehn R, Zwiener I, Zeller T, Lackner K, et al. Myopia and level of education: results from the Gutenberg Health Study. Ophthalmology. 2014;121(10):2047-52.

17. Fernandez-Montero A, Olmo-Jimenez JM, Olmo N, Bes-Rastrollo M, Moreno-Galarraga L, Moreno-Montanes J, et al. The impact of computer use in myopia progression: a cohort study in Spain. Prev Med. 2015 71:67-71.

18. Onal S, Toker E, Akingol Z, Arslan G, Ertan S, Turan C, et al. Refractive errors of medical students in Turkey: one year follow-up of refraction and biometry. Optom Vis Sci. 2007:84(3):175-80.

19. Loman J, Quinn GE, Kamoun L, Ying GS, Maguire MG, Hudesman D, et al. Darkness and near work: myopia and its progression in third-year law students. Ophthalmology. 2002;109(5):1032-8.
20. Lv L, Zhang Z. Pattern of myopia progression in Chinese medical students: a two-year follow-up study. Graefe's archive for clinical and experimental ophthalmology = Albrecht von Graefes Archiv fur klinische und experimentelle Ophthalmologie. 2013;251(1):163-8.

21. Riegelman RK. Medical Student Myopia Syndrome: a recently recognized pan-epidemic. Am J Prev Med. 1991;7(4):252.

22. Woo W, Lim K, Yang H, Lim X, Liew F, Lee Y, et al. Refractive errors in medical students in Singapore. Singapore Med J. 2004:45:470-4.

23. Midelfart A, Aamo B, Sjohaug KA, Dysthe BE. Myopia among medical students in Norway. Acta Ophthalmol (Copenh). 1992;70(3):317-22.

24. Mozolewska-Piotrowska K, Stepniewska J, Nawrocka J. [Frequency and incidence of myopia among medical students]. Klinika Oczna. 2005; 107(7-9):468-70.

25. Akhanda $\mathrm{AH}$, Quayum MA, Siddiqui NI, Hossain MM. Refractive status of medical students of mymensingh medical college. Mymensingh Med J. 2010;19(4):493-6.

26. Al-Rashidi SH, Albahouth AA, Althwini WA, Alsohibani AA, Alnughaymishi AA, Alsaeed AA, et al. Prevalence Refractive Errors among Medical Students of Qassim University, Saudi Arabia: Cross-Sectional Descriptive Study. Open Access Maced J Med Sci. 2018;6(5):940-3.

27. Dey AK, Chaudhuri SK, Jana S, Ganguly P, Ghorai S, Sarkar A. Prevalence of refractive errors in medical students. Int $\mathrm{J}$ Health Sci Res. 2014;4(8):98-102.

28. Al-Rashidi SH, Albahouth AA, Althwini WA, Alsohibani AA, Alnughaymishi AA, Alsaeed AA, et al. Prevalence Refractive Errors among Medical Students of Qassim University, Saudi Arabia: Cross-Sectional Descriptive Study. Open Access Macedonian J Med Sci. 2018;6(5):940.

29. Wang L, Du M, Yi H, Duan S, Guo W, Qin P, et al. Prevalence of and Factors Associated with Myopia in Inner Mongolia Medical Students in China, a cross-sectional study. BMC Ophthalmology. 2017;17(1):52.

30. Halari MM, Halari CD, Adeiza OD, Calista IU, Ayotunde AH. Prevalence of Eye Defects Among Medical Students in Dominica. ASRJETS. 2016; 18(1):133-41.

31. Arellano G, Chávez A, Arellano S, Chaves C. Estudio de la agudeza visual y problemas refractivos en estudiantes de medicina de la escuela superior politécnica de chimborazo 2013. SCientifica. 2014;12:25.

32. Kinge B, Midelfart A, Jacobsen G, Rystad J. The influence of near-work on development of myopia among university students. A three-year longitudinal study among engineering students in Norway. Acta Ophthalmologica Scandinavica. 2000;78(1):26-9.

33. Zhu X, Lin T, Stone RA, Laties AM. Sex differences in chick eye growth and experimental myopia. Exp Eye Res. 1995;61(2):173-9.

34. Xie H, Mao X, Yang H, Xie Z, Pan Y, Gao Y. [Analysis on the relationship between adolescent myopia and serum sex hormone]. Zhonghua $\mathrm{Yi}$ Xue Za Zhi. 2014;94(17):1294-7.

35. Hirsch MJ. Sex differences in the incidence of various grades of myopia Am J Optom Arch Am Acad Optom. 1953;30(3):135-8.

36. Rudnicka AR, Kapetanakis VV, Wathern AK, Logan NS, Gilmartin B, Whincup $\mathrm{PH}$, et al. Global variations and time trends in the prevalence of childhood myopia, a systematic review and quantitative meta-analysis: implications for aetiology and early prevention. $\mathrm{Br} \mathrm{J}$ Ophthalmol. 2016;100(7):882-90

37. Bar Dayan Y, Levin A, Morad Y, Grotto I, Ben-David R, Goldberg A, et al. The changing prevalence of myopia in young adults: a 13-year series of population-based prevalence surveys. Invest Ophthalmol Vis Sci. 2005;46(8):2760-5.

38. Mandel Y, Grotto I, El-Yaniv R, Belkin M, Israeli E, Polat U, et al. Season of birth, natural light, and myopia. Ophthalmology. 2008;115(4):686-92.

39. Zylbermann $R$, Landau $D$, Berson $D$. The influence of study habits on myopia in Jewish teenagers. J Pediatr Ophthalmol Strabismus. 1993; 30(5):319-22.

40. Morgan IG, Cotch MF. Birth order and myopia: what are the messages to readers? Ophthalmic Epidemiol. 2013;20(6):333-4

41. Wenbo L, Congxia B, Hui L. Genetic and environmental-genetic interaction rules for the myopia based on a family exposed to risk from a myopic environment. Gene. 2017;626:305-8.

42. Czepita D, Mojsa A, Ustianowska M, Czepita M, Lachowicz E. The effect of genetic factors on the occurrence of myopia. Klinika Oczna. 2011; $113(1-3): 22-4$

43. Feng $C Y$, Huang $X Q$, Cheng $X W$, Wu RH, Lu F, Jin ZB. Mutational screening of SLC39A5, LEPREL1 and LRPAP1 in a cohort of 187 high myopia patients. Scientific Reports. 2017;7(1):1120.

44. Jiang D, Li J, Xiao X, Li S, Jia X, Sun W, et al. Detection of mutations in LRPAP1, CTSH, LEPREL1, ZNF644, SLC39A5, and SCO2 in 298 families with early-onset high myopia by exome sequencing. Invest Ophthalmol Vis Sci. 2014;56(1):339-45

45. Guo $K$, Yang da $Y$, Wang $Y$, Yang $X R$, Jing $X X$, Guo $Y Y$, et al. Prevalence of myopia in schoolchildren in Ejina: the Gobi Desert Children Eye Study. Invest Ophthalmol Vis Sci. 2015;56(3):1769-74.

46. Battersby K, Koy L, Phillips N, Sim J, Wilk J, Schmid KL. Analysis of physical activity in emmetropic and myopic university students during semester and holiday periods: a pilot study. Clin Exper Optom. 2015; 98(6):547-54. 
Rev Mex Oftalmol (Eng). 2019;93

47. Muhamedagic L, Alajbegovic-Halimic J, Muhamedagic B, Muracevic B. Relation between physical activity and myopia progression in student population.Med Glas (Zenica). 2013;10(2):385-90.

48. Rudnicka AR, Owen CG, Richards M, Wadsworth ME, Strachan DP. Effect of breastfeeding and sociodemographic factors on visual outcome in childhood and adolescence. Am J of Clin Nutr. 2008;87(5):1392-9.

49. Ku PW, Steptoe A, Lai YJ, Hu HY, Chu D, Yen YF, et al. The Associations between Near Visual Activity and Incident Myopia in Children: A Nationwide 4-Year Follow-up Study. Ophthalmology. 2019;126(2):214-20.

50. Ip JM, Saw SM, Rose KA, Morgan IG, Kifley A, Wang JJ, et al. Role of near work in myopia: findings in a sample of Australian school children. Invest Ophthal Vis Sci. 2008;49(7):2903-10.

51. Rosner M, Laor A, Belkin M. Myopia and stature: findings in a population of 106,926 males. Eur J Ophthalmol. 1995;5(1):1-6.

52. Saw SM, Chua WH, Hong CY, Wu HM, Chia KS, Stone RA, et al. Height and its relationship to refraction and biometry parameters in Singapore Chinese children. Invest Ophthalmol Vis Sci. 2002;43(5):1408-13.

53. Erna R, Husin S, Harahap DH, Randana MPC. Correlation between Body Mass Index and Myopia in Medical Student Universitas Sriwijaya Palembang Indonesia. J Res Med Dent Sci. 2017;5(6):30-2.
54. Hashemi H, Khabazkhoob M, Asharlous A, Soroush S, Yekta A, Dadbin N, et al. Cycloplegic autorefraction versus subjective refraction: the Tehran Eye Study. Br J Ophthalmol. 2016;100(8):1122-7.

55. Fotouhi A, Morgan IG, Iribarren R, Khabazkhoob M, Hashemi H. Validity of noncycloplegic refraction in the assessment of refractive errors: the Tehran Eye Study. Acta Ophthalmologica. 2012;90(4): 380-6.

56. Mimouni M, Zoller L, Horowitz J, Wygnanski-Jaffe T, Morad Y, Mezer E. Cycloplegic autorefraction in young adults: is it mandatory? Graefe's archive for clinical and experimental ophthalmology. Albrecht von Graefes Archiv fur Klinische und Experimentelle Ophthalmologie. 2016;254(2): 395-8.

57. Sanfilippo PG, Chu BS, Bigault O, Kearns LS, Boon MY, Young TL, et al. What is the appropriate age cut-off for cycloplegia in refraction? Acta Ophthalmologica. 2014;92(6):e458-62.

58. Bai $Y, Y i ~ H, Z$ hang L, Shi Y, Ma X, Congdon N, et al. An investigation of vision problems and the vision care system in rural china. Southeast Asian J Trop Med Public Health. 2014;45(6):1464-73.

59. Zadnik K, Mutti DO. Refractive error changes in law students. Am J Optom Physiol Opt. 1987;64(7):558-61. 